\title{
Impact of Tree Size and Container Volume at Planting, Mulch, and Irrigation on Acer rubrum L. Growth and Anchorage
}

\author{
Edward F. Gilman, Jason Miesbauer, Chris Harchick, and Richard C. Beeson
}

\begin{abstract}
Some trees uproot in storms apparently due to root deflections that occur during nursery production. Root deflection in a nursery container may lead to poor anchorage because of insufficient root growth into the landscape soil, and container volume/tree size at planting may influence root deflection. This study was designed to evaluate establishment, root growth, and anchorage six years after planting Acer rubrum L. trees of four different sizes from four corresponding container volumes and maintaining them with two irrigation regimes. Impact of mulch on establishment and root growth was also evaluated. Trees from the largest containers grew slowest in the first three years due primarily to water stress. Trunk tilt during winching tests increased due to greater root deflection, less mass of the root-soil plate, and reduced root growth into the landscape soil with increasing container volume and tree size. In contrast to the poorly anchored larger trees that had most of their large roots retained in the original planted root ball volume, the largest roots on trees from smaller containers grew freely into landscape soil. This resulted in stable trees with many stiff, straight roots pushing down against mineral landscape soil outside the root ball during winching. Trees planted from smaller containers appear to anchor sooner than trees from larger containers and would be more stable in a storm.

Key Words. Bending Stress; Container Production; Root-soil Plate; Straight Roots.
\end{abstract}

Roots that naturally arise on trees originating from seeds (seeded-in-place) develop in concert with soil conditions; whereas, roots of planted trees are forced to acclimate to the new environment. Cultural practices in nurseries influence the position and shape of the largest roots (Ortega et al. 2006; Hewitt and Watson 2009) and the orientation of the root tips (Salonius et al. 2000), which dictate early root growth of trees in their new location. Nursery-induced changes in root morphology have been associated with delayed establishment and poor anchorage compared to trees seeded-in-place (Lindström and Rune 1999).

Coutts (1983), Stokes (1999), and others have studied tree anchorage and stability in plantation-grown forest stands. Models for some species can explain a sizable portion of variation in tree stability from mass of the root-soil plate (RP), rooting depth, morphology, and soil type (Fourcaud et al. 2008). Though advances have been made in describing the mechanics of tree anchorage on trees seeded-in-place or planted from small root balls typical of plantations, few studies have been performed on trees planted from the much larger root balls typical in urban landscapes.

Modeling root growth rates in USDA Hardiness Zone 5 (Illinois, U.S.), Watson (1985) suggested that small nursery stock [10 cm trunk diameter (caliper)] would establish and grow quicker than larger trees. Gilman et al. (1998) confirmed that small caliper live oak (Quercus virginiana Mill.) trees (6.3 $\mathrm{cm})$ planted into the landscape in zone 8 (Florida, U.S.) from nursery containers grew at a faster rate than larger trees, but not when transplanted from a field nursery. Furthermore, the smaller field-grown trees were the same size as the containergrown trees that started out much larger three years earlier. This is likely due to greater defoliation and water stress for trees planted from larger containers (Gilman et al. 2010a). Struve et al. (2000) suggested that smaller trees in their study did not grow faster to become equivalent in size to the larger trees because the larger trees in that nursery were typically the most vigorous and therefore grew fastest. This keen observation has merit when comparing trees from the same block of trees in the same nursery, but may not hold true when comparing small trees from one nursery with larger trees from a different block or from a different nursery. These studies suggest that tree size and root ball volume at planting impact establishment and growth rate of trees in urban landscapes. However, there is no information on establishment and anchorage of trees planted from containers larger than about $170 \mathrm{~L}$.

Susceptibility to drought stress for trees planted from containers with soilless (typically bark, organic matter, and sand) substrate has been attributed to a dense root system inside the container (Harris and Gilman 1993) that dries quickly (Marshall and Gilman 1998) because of low water-holding capacity (Spomer 1980). The low substrate density of a soilless container root ball also increases susceptibility of overturning in storms compared to trees transplanted from a field nursery with a heavier mineral soil root ball (Gilman and Masters 2010). Trees grown in a soil-based substrate in containers have not been studied.

Mulch and irrigation management can drastically impact soil properties (Scharenbroch 2009) and tree establishment rate (Gilman and Grabosky 2004), and could influence anchorage by impacting root growth. Mulch application to the surface of a planted root ball and to the surrounding soil of relatively young trees has been associated with reduced tree survival (Arnold 2005; Singer and Martin 2009), slightly enhanced growth rate (Arnold and 
McDonald 2009), or no impact (Singer and Martin 2009). There is limited testing of mulch application on large nursery stock.

This study was designed to test the influence of initial nursery stock size (in containers of AAN standard volume, 2004) and post-planting irrigation management on red maple (Acer rubrum L.) growth and anchorage six years after installation. Impacts of post-planting mulch application on growth attributes were also evaluated. Red maple was chosen due to the popularity of trees in the Acer genus in temperate regions in the northern hemisphere (Iles and Vold 2003).

\section{MATERIALS AND METHODS}

\section{Treatments and Planting}

In late February and early March 2006, 64 red maples (Acer rubrum L. 'Florida Flame') propagated from cuttings were planted $4.6 \mathrm{~m}$ apart, in four rows of 16 trees, into field soil from black, smooth-sided plastic containers of four different volumes $(16$ trees from each): $11 \mathrm{~L}(28 \mathrm{~cm}$ wide $\times 24 \mathrm{~cm}$ tall; trees $2.5 \mathrm{~cm}$ caliper, $2.4 \mathrm{~m}$ tall), $103 \mathrm{~L}(60 \mathrm{~cm}$ wide $\times 46 \mathrm{~cm}$ tall; trees 6.8 $\mathrm{cm}$ caliper, $4.6 \mathrm{~m}$ tall $), 230 \mathrm{~L}(78 \mathrm{~cm}$ wide $\times 59 \mathrm{~cm}$ tall; trees $9.3 \mathrm{~cm}$ caliper, $5.1 \mathrm{~m}$ tall), and $983 \mathrm{~L}(147 \mathrm{~cm}$ wide $\times 66 \mathrm{~cm}$ tall; trees $15.7 \mathrm{~cm}$ caliper, $7.6 \mathrm{~m}$ tall). Tree dimensions were in compliance with ANSI Z-60 National Standards (AAN 2004). Four trees from each container volume were randomly assigned to a position in one block of 16 adjacent trees. Field soil was Millhopper fine sand (loamy, siliceous, hyperthermic Grossarenic Paleudults) with less than $2 \%$ organic matter and a bulk density of $1.51 \mathrm{~g} / \mathrm{cc}$ in USDA Hardiness Zone $8 \mathrm{~b}$ in Gainesville, Florida, U.S. Wire baskets were installed into the root balls of the $983 \mathrm{~L}$ containers three years prior to landscape planting to facilitate lifting. Holes 10 to $15 \mathrm{~cm}$ wider than the root balls were dug with straight sides and flat bottoms and adjusted so the top of the undisturbed root ball was about even with the landscape soil surface. One person packed the bottom of holes by foot in an effort to standardize settling. Water was added to settle backfill soil and soil was packed firmly by foot to standardize compaction of backfill soil. No berm or water ring was constructed around the root balls and no mulch was applied. Weeds were kept clear in the plot with periodic (3 to 4 annually) applications of glyphosate (isopropylamine salt, $41 \%$ ).

Trees were irrigated daily through $2(11 \mathrm{~L}), 3(103 \mathrm{~L}), 4(230 \mathrm{~L})$, or 6 (983 L) Roberts Spot-Spitters (Roberts Irrigation Products, Inc. San Marcos, Idaho, U.S.) positioned at the edge of the root ball directed toward the trunk through May 8, 2006 (57 L per irrigation the first three weeks followed by $26 \mathrm{~L}$ thereafter for $983 \mathrm{~L}$ containers, $19 \mathrm{~L}$ for $230 \mathrm{~L}$ containers, $13 \mathrm{~L}$ for $103 \mathrm{~L}$ containers, and $9 \mathrm{~L}$ for $11 \mathrm{~L}$ containers). This was followed by approximately two weeks of no irrigation in order to evaluate xylem water potential under water deficit conditions. Irrigation resumed to every other day May 24 with $983 \mathrm{~L}$ containers receiving $82 \mathrm{~L}, 230 \mathrm{~L}$ containers receiving $34 \mathrm{~L}, 103 \mathrm{~L}$ containers receiving $23 \mathrm{~L}$, and $11 \mathrm{~L}$ containers receiving $11 \mathrm{~L}$; volume was increased because the weather remained dry, which was normal for the region in that season. In April 2007, half the trees for each container volume in each block were irrigated Monday, Wednesday, and Friday; the other half received no additional irrigation. In May 2007 (14 months after planting), half the irrigated trees from each container size and irrigation treatment in each block received an $8 \mathrm{~cm}$ thick layer of shredded hardwood mulch to within several centimeters of the trunk from line-clearing operations. Mulch was applied to a $4.6 \mathrm{~m} \times 4.6 \mathrm{~m}$ square around each tree. A $5 \mathrm{~cm}$ layer was added at the beginning of year three to make up for decomposition. There was one tree in each block that received each of the 16 treatment combinations. Trees were not fertilized at or after planting.

\section{Tree Measurements}

Two wooden stakes were driven into soil $90 \mathrm{~cm}$ east and west of the trunk in undisturbed soil to monitor tree subsidence or settlement following planting. A string was stretched tight from the top of each stake so it rested against the trunk. A visible line was drawn on the trunk to mark string position at planting March 2006 and two growing seasons later in October 2007. Abnormal vertical cracks developing on the lower $2 \mathrm{~m}$ of trunks possibly due to transplant water stress were counted in October 2007.

Irrigation was withheld during eight periods of dry weather (May 2006 through April 2007) during the first year after planting to induce short periods of sub-lethal water stress. Xylem water potential was measured $12: 00$ to $14: 00 \mathrm{hr}$ on sunny or mostly sunny days with a pressure chamber (Soil Moisture Inc., Santa Barbara, California, U.S.) on all 64 trees. Terminal portions $(10 \mathrm{~cm}$ long) of current year twigs growing in full sun about half way up the southern side of the crown were immediately placed in the pressure chamber for measurement. Trunk diameter at $30 \mathrm{~cm}$ above the ground and total tree height were measured at planting and each September except in 2010 when only diameter was measured.

\section{Evaluating Anchorage}

The Alachua County, Florida, soil survey was used to determine the amount of water to add $(757 \mathrm{~L})$ and amount of time to wait (6 hours) to bring a $2.4 \mathrm{~m} \times 2.4 \mathrm{~m} \times 1.2 \mathrm{~m}$ deep volume of soil around each tree to field capacity. The actual amount of water added was 1.5 times the amount needed $(757 \mathrm{~L} \times$ $1.5=1135 \mathrm{~L}$ ), to ensure soil saturation consistency. Water was applied through four low-profile sprinkler heads. Each tree was winched 6.0 to 6.5 hours after irrigation ceased thus allowing water to percolate into soil and drain, bringing soil to field capacity prior to evaluating tree anchorage. Water application simulated a large volume rain event often associated with storms, and standardized soil moisture conditions among replicates due to reported influence of soil moisture on anchorage (Kamimura et al. 2012).

The researchers did not expect mulch to influence anchorage so non-mulched trees were not winched. All 32 trees in the mulched treatments were winched with a steel cable and electric winch (Model 40764; Chicago Electric Power Tools, Inc. Camarillo, California, U.S.), August 4-16, 2011, in the 350 degree Azimuth (from north) direction to evaluate lateral tree stability (anchorage). This direction was chosen so tree crowns would not touch one another as they were winched. There was no prevailing wind direction at the site. Mulch was gently raked from the surface to better observe RP movement during winching. An electronic inclinometer (model 3DM-GX1, Microstrain Inc., Vermont, U.S.) was secured with screws to the trunk base $15 \mathrm{~cm}$ from soil surface, immediately above the swollen flare. A $3,629 \mathrm{~kg}$ capacity load cell (SSM-AF-8000; Interface Inc., Scottsdale, Arizo- 
na, U.S.) was placed in-line with the steel cable attached to the trunk, 1 (smaller trees) to about 2.5 (larger trees) meters from ground. Trees were winched so their cable was parallel to ground by mounting the winch on an adjustable tractor bucket.

Winching occurred at $2 \mathrm{~cm} \cdot \mathrm{s}^{-1}$ until calculated bending stress was $10,342 \mathrm{kN} / \mathrm{m}^{2}$. This was chosen as the lowest stress because it resulted in very little trunk tilt (about 1 degree) during several practice pulls on trees from the non-mulched plots. Winching to a constant bending stress was used to simulate exposure to a given wind speed. A stress of $24,132 \mathrm{kN} / \mathrm{m}^{2}$ was chosen as the upper limit because practice pulls showed it resulted in significant and permanent rotation of root balls as observed in wind storms. Three stresses $\left(13,790 ; 17,237\right.$; and $\left.20,684 \mathrm{kN} / \mathrm{m}^{2}\right)$ between these were chosen for a total of five equidistant (orthogonal) bending stresses per tree. The tree was held in position at each stress while RP attributes were measured, and then cable was let slack. Trunk tilt (angle change from vertical start position) was recorded during the winching and 60 seconds after the cable went slack (referred to as resting angle). During winching, load cell and inclinometer measurements were sampled at $20 \mathrm{~Hz}$ using a 16-bit data acquisition system (National Instruments Corporation, Austin, Texas, U.S.), and displayed and archived in real-time on a laptop running LabView software (v: 7.0; National Instruments, Austin, Texas, U.S.). The trunk bending stress was calculated as: (force $\times$ distance from pulling point to inclinometer $\times$ trunk radius at inclinometer calculated from a diameter tape measurement $) \div\left(0.25 \pi \times\right.$ trunk radius $\left.{ }^{4}\right)$.

As trees were held in position at each stress, several attributes of the RP were measured within a narrow triangular area defined by 5 degrees either side of the axis of the cable on the windward (away from winch) and winchward (toward the winch) sides. These attributes included distance from the trunk bark at soil line to the lowest point on the winchward side (RP hinge point, Figure 6) and highest point on the windward side (RP lift point); and distance from the trunk to the far edge of the soil depression (winchward RP edge), and to the far edge of the lifted plate (windward RP edge).

Two brightly colored screws were inserted into the trunk 5 to $7 \mathrm{~cm}$ from the ground above the trunk flare, one on the windward and one on the winchward side along the winching axis. Two video cameras pointed at the trunk base were mounted side-by-side near ground level $1 \mathrm{~m}$ from the trunk and perpendicular to the winching axis. Each screw was centered in the viewfinder of the respective camera to record vertical and horizontal distance traveled (displacement) on the winchward and windward side of the trunk. A ruler fixed to the trunk directly above each screw was used as a scale to measure the displacement of each colored screw during video playback.

An air excavation device was used in October 2011 to expose roots on the winchward and windward side of each tree in a one-quarter (90 degree) arc centered on the axis of the winching direction. Soil was removed from the edge of the original planted root ball and about $40 \mathrm{~cm}$ beyond to a depth of about $20 \mathrm{~cm}$. Diameter of the five largest roots in each arc (10 total per tree) was measured with a micro-caliper $15 \mathrm{~cm}$ from the planted root ball edge. Diameter was measured topto-bottom and side-to-side, and the mean of these two measurements was used as the diameter of a circle to calculate cross-sectional area (CSA) of each root. The number of roots (of the 5 largest measured in the two exposed arcs just inside the original root ball edge) that did not appear to be deflected by the container was also recorded for each tree. This was used to calculate the percent of the five largest roots not deflected.

\section{Experimental Design and Statistical Analysis}

The study was designed as a three-way factorial in a randomized complete block design with 4 container volumes $\times 2$ irrigation treatments $\times 2$ mulch treatments $=16$ trees in each of four blocks. Three-way repeated measures analysis of variance (ANOVA), with time as the within-subjects factor, was used to evaluate impact of main effects and interactions on trunk diameter, tree height, and xylem potential (SAS GLM procedure, SAS Institute, Cary, North Carolina, U.S.). Means were separated with LSMEANS procedure. Three-way ANOVA was used to evaluate the impact of main effects and interactions on trunk settlement and trunk cracks; Duncan's multiple range test (MRT) was used to separate main effects. Trunk CSA, root CSA, percentage of five largest roots not deflected, trunk angle, trunk rest angle, winchward hinge point, winchward plate edge, windward lift point, windward plate edge, and horizontal and vertical trunk displacement during winching were analyzed using two-way repeated measures ANOVA, with bending stress as the within-subjects factor and container volume and irrigation as main effects. Means were separated with LSMEANS. SAS STEPWISE procedure was used to calculate the best predictive model of horizontal and vertical trunk displacement from bending stress and various measured tree attributes. Coefficients of determination $\left(\mathrm{R}^{2}\right)$ for the linear relationship between trunk angle and vertical or horizontal trunk displacement during winching were calculated with SAS GLM procedure. Significant results were reported at $P<0.05$ unless indicated.

\section{RESULTS AND DISCUSSION}

\section{Growth and Establishment}

No interactions among container volume, mulch, and irrigation were significant for any measured parameter. Repeated measures ANOVA showed the main effects of container volume, mulch and irrigation on xylem water potential, trunk diameter, and tree height depended on when the trees were measured.

Tree settlement and trunk cracks formed after planting were not affected by irrigation or mulch; however, both were impacted by container volume (Table 1). Settlement distance increased with container volume; trees from the smallest containers $(11 \mathrm{~L})$ actu-

Table 1. Tree settlement during the first two growing seasons (March 2006 through October 2007) and trunk cracking after planting into field soil from four nursery container volumes.

\begin{tabular}{lll}
\hline $\begin{array}{l}\text { Container volume } \\
\text { at planting }(\mathrm{L})\end{array}$ & $\begin{array}{l}\text { Tree settlement } \\
\text { (mm) }\end{array}$ & $\begin{array}{l}\text { Number of vertical } \\
\text { cracks per trunk }\end{array}$ \\
\hline 11 & $+3(0$ to +16$) \mathrm{a}^{\mathrm{y}}$ & $0.1 \mathrm{~b}$ \\
103 & $-1(-5$ to 0$) \mathrm{a}$ & $0 \mathrm{~b}$ \\
230 & $-6(-16$ to 0$) \mathrm{b}$ & $0.1 \mathrm{~b}$ \\
983 & $-26(-32$ to -2$) \mathrm{c}$ & $5.3 \mathrm{a}$ \\
\hline
\end{tabular}

${ }^{\mathrm{z}}$ Settlement: negative number indicates that tree trunk sank into soil in the first 17 months after planting; positive number indicates trees lifted up out of the soil. Number in parenthesis indicates range.

${ }^{y}$ Means in a column with a different letter are statistically different at $P<0.05$ and were compared with Duncan's MRT ( $\mathrm{n}=16$, averaged across irrigation and mulch treatments). 
ally lifted slightly in the 17 months after planting as Gilman and Masters (2010) found for small field-grown trees. Settlement has been attributed to greater soil mass over the root ball when trees were planted deeply (Gilman and Grabosky 2011). This appears to coincide with the current study where the heavier trees (i.e., those from the larger containers) subsided most. Trees settling into the decomposing substrate of the planted container root ball can encourage new roots to grow over main structural roots that could become stem-girdling roots (Gilman and Grabosky 2011). Numerous vertical cracks through the bark, also described by Roppolo and Miller (2001),

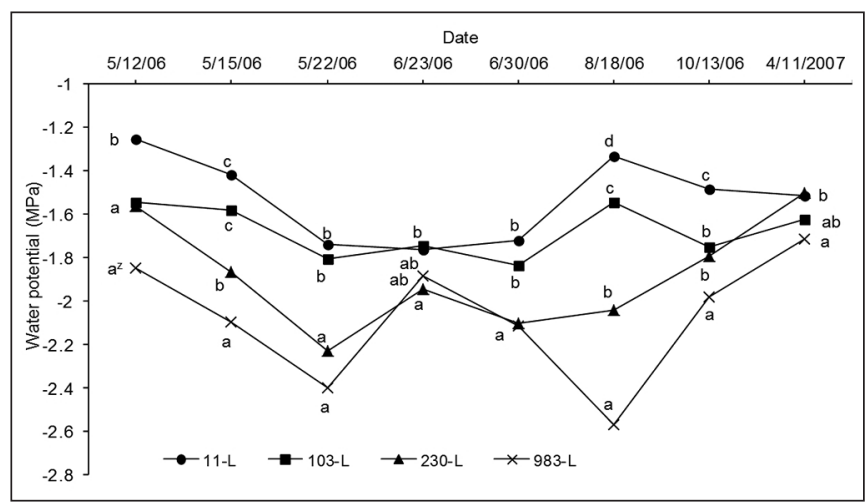

Figure 1. Midday stem xylem potential during the first year after planting trees from four container volumes. Different letters for each date indicate significant difference among volumes $(n=16$, averaged across mulch and irrigation, $P<0.05$ ).

appeared along the trunks of trees from the largest containers a few months after planting (Table 1) and were likely due to water stress. In the first 13 months, trees from larger containers experienced more water stress (they had a more negative xylem potential) than from smallest containers for all eight dry periods (Figure 1), which probably induced the cracks. Difference in mean xylem potential among the other container volumes depended on the sampling date with greater separation as water potential became more negative.

Tree height and trunk diameter growth were similar among the three smaller container volumes the first three and six years after planting, respectively (Figure 2). Although trees from the largest container volume $(983 \mathrm{~L})$ remained significantly larger six years after planting, those from the smallest three container volumes equally gained (evaluated by repeated measures ANOVA) $2 \mathrm{~cm}(P<0.01)$ in trunk diameter and 2.2 $\mathrm{m}(P<0.01)$ in height more than trees planted from the largest containers by the study's end. This was due primarily to slower growth in trunk diameter and height in the second and third year on trees planted from the largest containers. Similar growth rates among all container volumes beginning four years after planting suggests that about three years was required for the largest trees to become established, or about six months for each $2.5 \mathrm{~cm}$ trunk diameter. This is about the time predicted from other studies in the same climate (Gilman et al. 1998).

Repeated measures ANOVA showed tree height was larger in the mulched plots than in non-mulched plots only two and three years after planting (Figure 3); mulch was not ap- plied the first year after planting, so no response was expected. Mulch was not associated with taller trees in other years. Trunk diameter in mulched plots at the end of the study was $13 \mathrm{~mm}$ greater than in the bare-ground plots representing about a $15 \%$ enhancement. The small growth response of red maple trees to mulch application agrees with other findings that tracked growth for several years after planting (e.g., Iles and Dossman 1999; Arnold and McDonald 2009), although the effects in those studies were not always apparent on all tested taxa.

Trunk diameter increased by $7 \mathrm{~mm}$ as a result of irrigation in the six years after planting (Figure 4) which, although statistically significant in three of the six years, seems inefficient given the large irrigation volume applied over the period. Tree height and root growth (data not shown) were not impacted by irrigation. Although root overlap from neighboring trees could have masked effects, others also showed limited growth response to irrigation following planting in a moist climate (Gilman et al. 1998; Gilman et al. 2003) and dry climate (Paine et al. 1992). By contrast, Stabler and Martin (2000), in the arid climate of Arizona, U.S., found a positive relationship between growth rate and irrigation frequency for two xeric tree species.

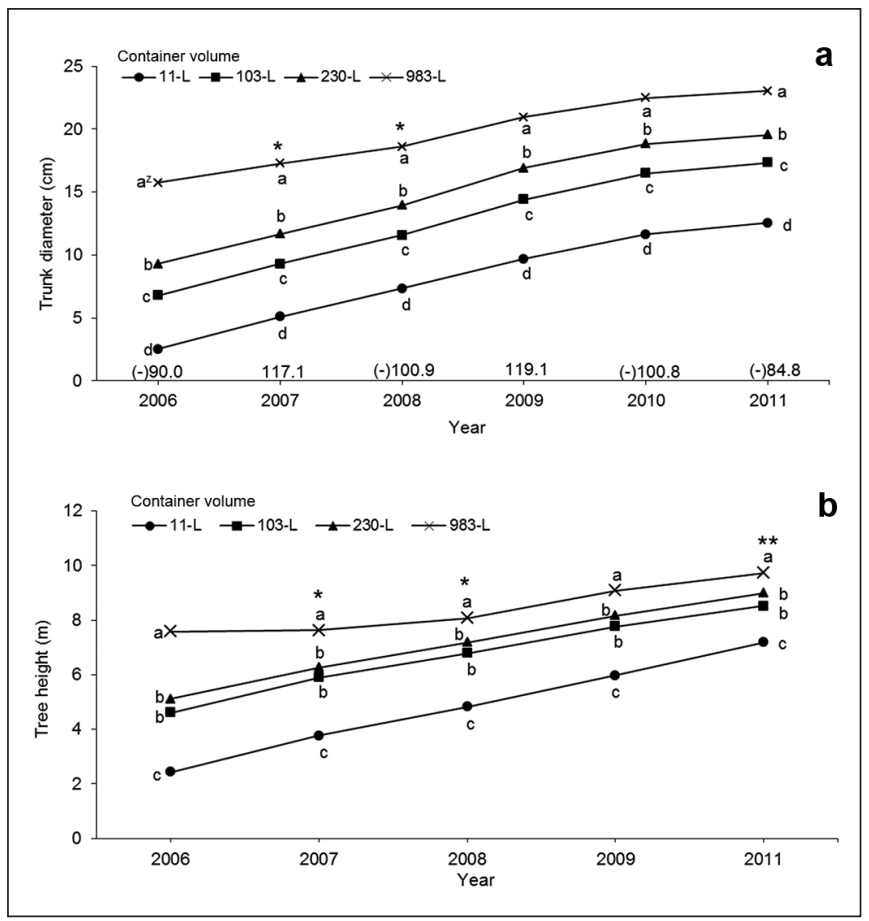

Figure 2. Trunk diameter (a) and tree height (b) measured each September on red maple planted from four container volumes. Asterisk $\left({ }^{*}\right)$ indicates years when caliper or height increase (i.e., current September minus prior September) for trees in $\mathbf{9 8 3}$ $L$ containers was less than the increase for all smaller sizes. Double asterisk $\left({ }^{* *}\right)$ indicates height increase from Sept 2009 to 2011 in $11 \mathrm{~L}$ containers was more than those in all other volumes. Different letters within a year indicate significant difference in caliper or height $(n=16$, averaged across mulch and irrigation treatments, $P<0.05$ ) among container volumes using LSMEANS. Rainfall $(\mathrm{cm})$ indicated above each year designation; rainfall was less than $90 \%$ of annual mean $(120 \mathrm{~cm})$ in years with a $(-)$. 


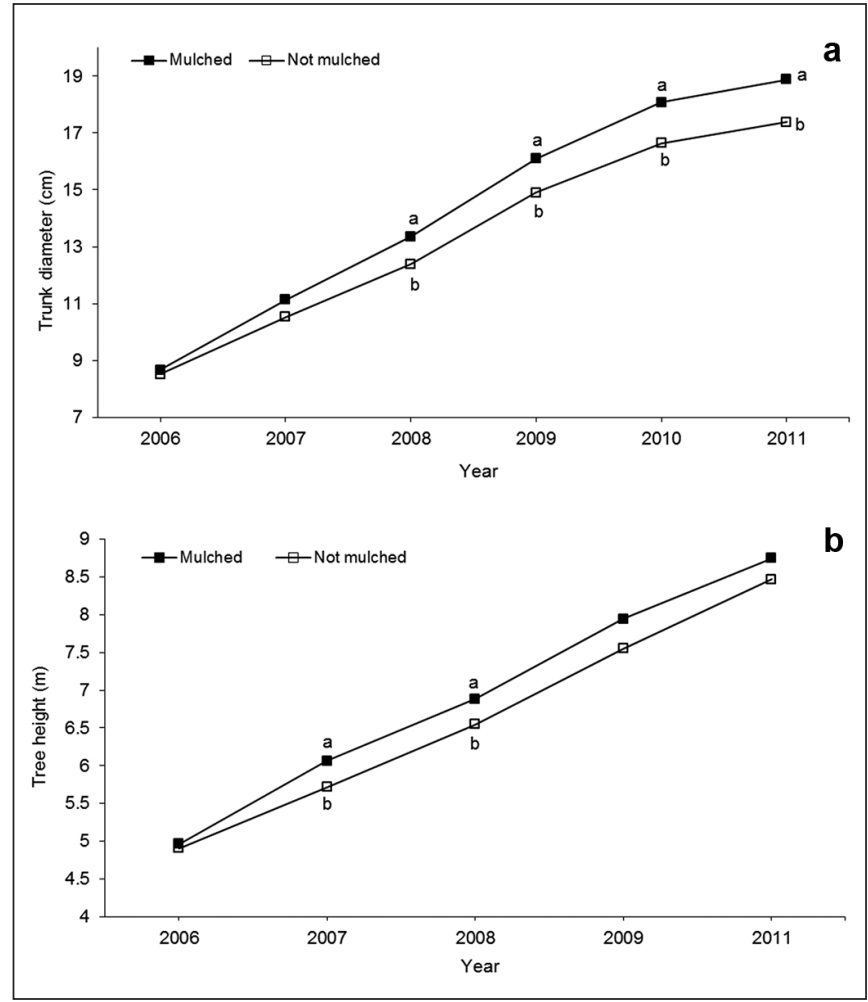

Figure 3. Trunk diameter (a) and tree height (b) measured each September (caliper only in 2010) on red maple planted in mulched and non-mulched plots. Different letters within a year indicate significant difference in caliper or height $(n=32$, averaged across container volume and irrigation, $P<0.05$ ) using LSMEANS.

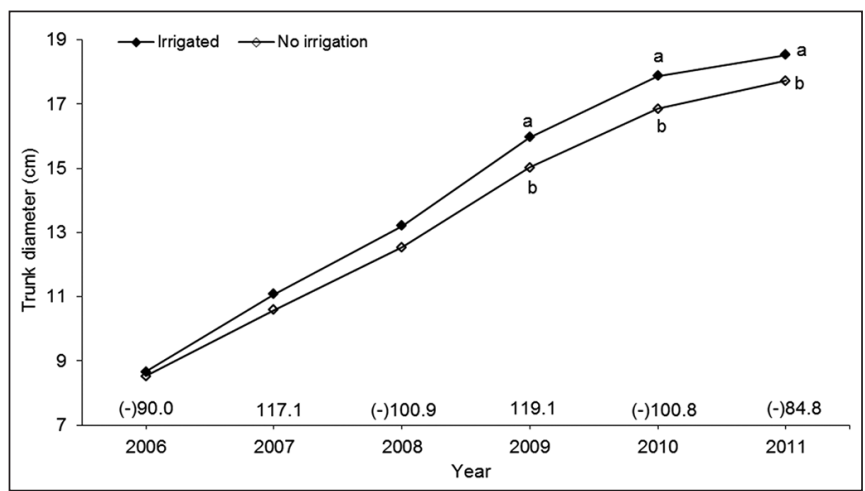

Figure 4. Trunk diameter measured each September on red maple planted from four container volumes. Different letters within a year indicate significant difference in diameter $(n=32$, averaged across mulch treatments and container volume, $P<0.05)$ using LSMEANS. Rainfall $(\mathrm{cm})$ indicated above each year designation; rainfall less than $90 \%$ of annual mean $(120 \mathrm{~cm})$ in years with a $(-)$.

\section{Anchorage}

There was no effect of irrigation on position of RP hinge point, or winchward and windward RP edge, or RP lift point as a result of winching (data not shown). Irrigation also did not impact trunk angle or trunk rest angle. However, both angles increased with container volume and bending stress, and differences in angle among volumes increased with stress (Figure 5).
Container volume impacted the position of both the winchward RP edge and windward RP lift point, but not the position of the RP hinge point or windward RP edge (Figure 6). Similar to Picea sitchensis (Coutts 1983), the position of the hinge and lift points changed little with increasing bending stress (Figure 6), indicating that a small bending stress can expose weak points in the root-soil plate. Roots at the RP hinge point on trees planted from the two smallest containers pushed down against mineral soil present in the landscape outside the original root ball (Figure 6a, left), which offered considerable resistance. By contrast, roots at the RP hinge point for the two largest containers pushed against decomposing soilless organic substrate within the root ball, which offered less resistance than mineral soil (Fraser and Gardiner 1967). This caused the RP hinge point to sink and resulted in greater trunk tilting. Moreover, the sudden decrease in root diameter at the transition point of one container to the next larger size, caused by root deflections (Gilman et al. 2010b), resulted in fewer straight roots on the larger trees and dramatically less root CSA in landscape soil (Table 2; Figure 7). Coutts (1983) also described sudden reductions in root diameter from branching points as sources of winchward hinge points and weakness, as did Gilman and Masters (2010) for live oak planted from containers.

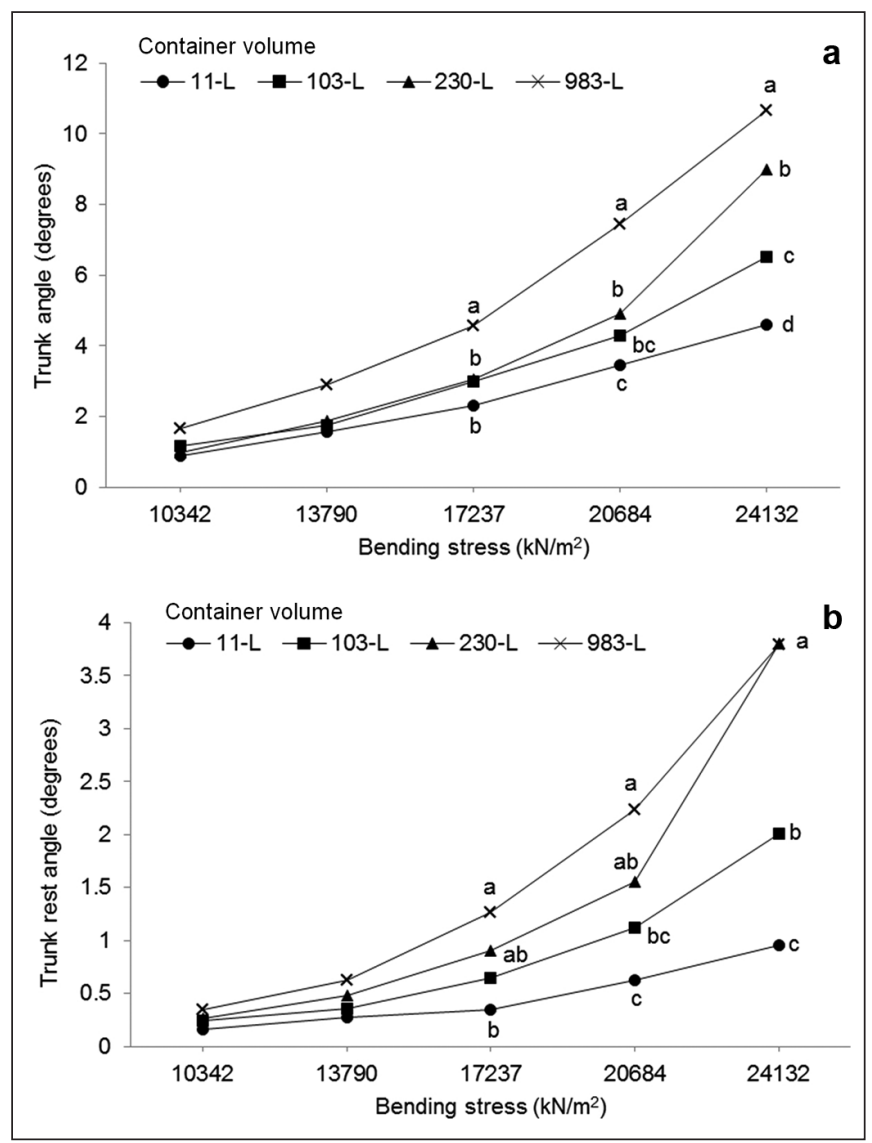

Figure 5. Trunk angle (a) at five applied bending stresses and rest angle (b) following cable release of trees planted from four container volumes. Different letters within a bending stress indicate significant difference in angle $(n=8$, averaged across irrigation, $P<0.05)$ using LSMEANS. 


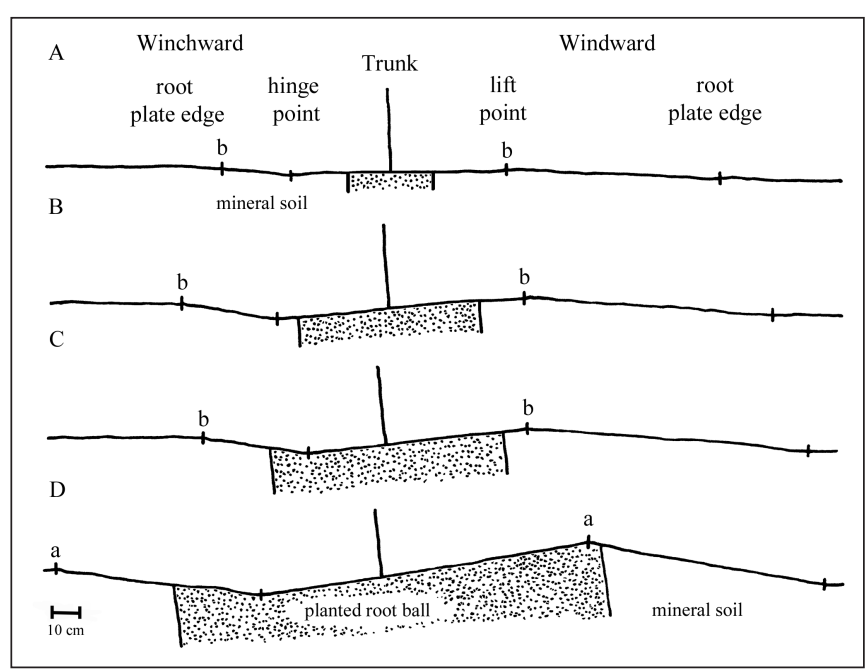

Figure 6. Distance between the trunk and the winchward rootsoil plate edge, winchward hinge point, windward lift point, and windward plate edge while winching trees to $24,132 \mathrm{kN} / \mathrm{m}^{2}$ bending stresses planted six years earlier from four container volumes ( $A=11 \mathrm{~L} ; \mathrm{B}=103 \mathrm{~L} ; \mathrm{C}=230 \mathrm{~L} ; \mathrm{D}=983 \mathrm{~L})$. Different letters in a column for each attribute indicate significant difference $(n=8$, averaged across irrigation, $P<0.05)$. Planted root ball depth is truncated for illustration purposes.

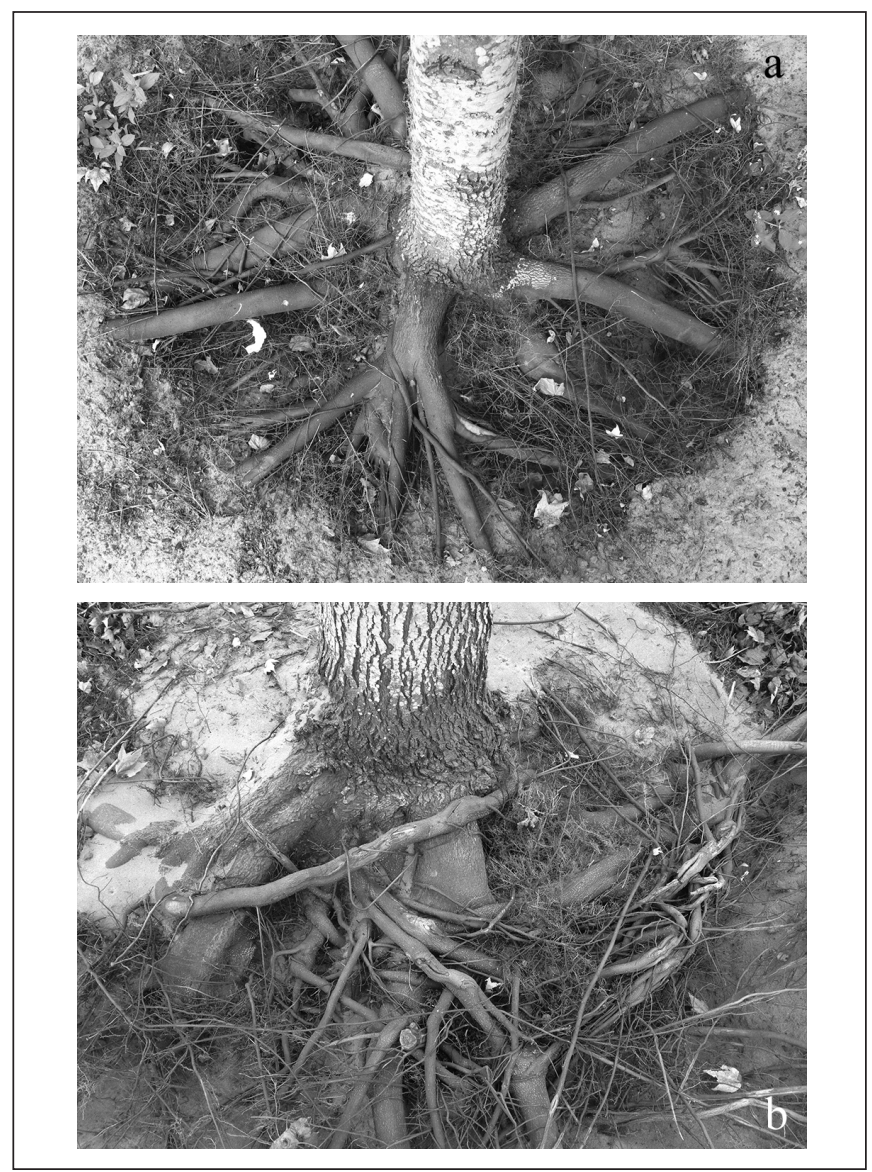

Figure 7. Exposed root system from trees planted six years earlier from an $11 \mathrm{~L}$ container (a) showing many large straight roots, and $983 \mathrm{~L}$ (b) container showing large deflected roots close to trunk (left) and only small roots growing into landscape soil (right).
Adding to the instability of trees from the larger containers was the dramatically higher ratio of trunk CSA: root CSA measured $15 \mathrm{~cm}$ distal to the edge of the planted root ball (Table 2) also reported by Gilman and Masters (2010). Sixty-seven to 69 percent of the variation in trunk angle and rest angle was attributed to a combination of the ratio trunk CSA: root CSA, container volume, and bending stress (Equation 1; Equation 2). A portion of the unexplained variation in angle could be due to root system configuration within the container root ball, a characteristic that is difficult to measure. Many past studies (e.g., Tanaka et al. 2012) showed that overturning resistance increases with trunk diameter, directly opposite results of the current study. This appeared primarily due to presence of the largest trees in the largest container volumes that had the most deformed root systems as reflected by the least root CSA outside of the planted root ball (Table 2). Increasing trunk tilt with trunk diameter is not unprecedented in that large trees were the most likely to fail in hurricanes (Duryea et al. 2007).

[1] Trunk angle during winching $=0.114$ (trunk CSA $\div$ total root CSA in largest 10 roots $)+\left[\left(1.32 \times 10^{-9}\right) \times\right.$ container volume $(\mathrm{L})]+\left[0.0005 \times\right.$ bending stress $\left.\left(\mathrm{kN} / \mathrm{m}^{2}\right)\right]-5.48 ; \mathrm{P}<$ $0.0001, \mathrm{R}^{2}=0.67$.

[2] Trunk rest angle after winching $=0.025$ (trunk CSA $\div$ CSA largest single root $)+\left[\left(1.75 \times 10^{-9} \times\right.\right.$ container volume $\left.(\mathrm{L})\right]+$ $\left[0.0005 \times\right.$ bending stress $\left.\left(\mathrm{kN} / \mathrm{m}^{2}\right)\right]-5.44 ; \mathrm{P}<0.0001, \mathrm{R}^{2}=0.69$.

Contributing to good anchorage of trees from smaller containers was the large RP in relation to the trunk diameter. Despite the large differences in trunk diameter (Figure 2), the RP on the windward side was the same length $(130 \mathrm{~cm})$ for all container volumes (Figure 6). Previous studies showed that RP depth, shape, and mass were responsible for a significant (13\%-45\%) portion of overturning resistance (Coutts 1983; Ennos 1995), although roots growing in the windward direction (Stokes 1999) and other factors (Fourcaud et al. 2008) also contribute. Moreover, the RP of the smaller containers in the current study was comprised of proportionally more mineral soil than that of larger containers (Figure 6) resulting in more mass in the RP of the smaller containers. The strategy of growing roots radially away from the base of the trunk, instead of deflecting down, up, or around, appears best suited for binding together a large mass of soil and roots into a RP that resists overturning of red maple.

Although sinking on the winchward side of the trunk increased slightly with bending stress equally for all container volumes $(P<0.01$, statistics not shown), trunks only sunk about $3 \mathrm{~mm}$ at the highest bending stress (Figure 8). However, horizontal trunk displacement toward the winch increased markedly with container volume and bending stress (Figure 8). Displacement was considerably more than the $1-5 \mathrm{~mm}$ reported in a previous study (Coutts 1983). Lateral displacement reached an average of more than $45 \mathrm{~mm}$ at the largest bending stress on the largest two container volumes (Figure 8), and it was highly correlated with trunk angle during $\left(\mathrm{R}^{2}=0.81\right)$ and immediately after (rest angle, $\mathrm{R}^{2}=$ 0.89 ) winching. Decomposition of the organic substrate inside the root ball undoubtedly contributed to weakness, thus allowing the trunk to shift (shear) laterally toward the winch and into the deepening depression at the RP hinge point. The deflected nature of roots in larger containers likely accounted for the large amount of horizontal displacement because only a small por- 
Table 2. Trunk and root cross-sectional area ${ }^{2}$ for trees planted into soil six years earlier from four nursery container volumes.

\begin{tabular}{|c|c|c|c|c|}
\hline $\begin{array}{l}\text { Container volume } \\
\text { at planting (L) }\end{array}$ & $\begin{array}{l}\text { Trunk cross-sectional } \\
\text { area }\left(\mathrm{cm}^{2}\right)\end{array}$ & $\begin{array}{l}\text { Root cross-sectional area } \\
\text { in landscape }\left(\mathrm{cm}^{2}\right)\end{array}$ & $\begin{array}{l}\text { Trunk CSA: } \\
\text { root } \mathrm{CSA}^{\mathrm{z}}\end{array}$ & $\begin{array}{l}\text { Percent of five largest } \\
\text { roots not deflected }(\%)^{\mathrm{y}}\end{array}$ \\
\hline 11 & $155 a^{x}$ & $114 \mathrm{~b}$ & $1.7 \mathrm{a}$ & $94 \mathrm{c}$ \\
\hline 103 & $267 \mathrm{~b}$ & $96 \mathrm{~b}$ & $4.2 \mathrm{a}$ & $53 \mathrm{~b}$ \\
\hline 230 & $321 \mathrm{c}$ & $32 \mathrm{a}$ & $11.3 \mathrm{ab}$ & $12 \mathrm{a}$ \\
\hline 983 & $459 \mathrm{~d}$ & $39 a$ & $18.4 \mathrm{~b}$ & $0 \mathrm{a}$ \\
\hline
\end{tabular}

${ }_{\mathrm{z}}$ Trunk CSA measured $30 \mathrm{~cm}$ above soil; total CSA of the five largest roots in north and south quadrants (10 total) measured $15 \mathrm{~cm}$ outside original planted root ball periphery; trunk CSA: root CSA ratio calculated as a mean for each tree.

y Percent of the five largest roots measured close to the trunk in the top $10 \mathrm{~cm}$ of the planted root ball that grew into landscape soil without deflection.

${ }^{x}$ Means in a column with a different letter are statistically different at $P<0.05$ and were compared with Duncan's MRT ( $\mathrm{n}=16$, averaged across irrigation and mulch treatments).

tion of the root system radiated straight in the windward direction (Table 2). Large diameter, straight roots that are relatively close to the soil surface on trees from the smaller containers reportedly stiffen the RP which increases resistance to overturning (Coutts 1983; Mickovski and Ennos 2002; Fourcaud et al. 2008; Gilman and Wiese 2012). This provides guidelines for optimum root form on nursery trees destined for the landscape.

Whether the root system in the long run compensates for the large mass of deflected roots in the planted root ball by growing roots in new positions remains unanswered. However, Coutts and Philipson (1977) showed that dominant roots on young trees are likely to also be dominant many

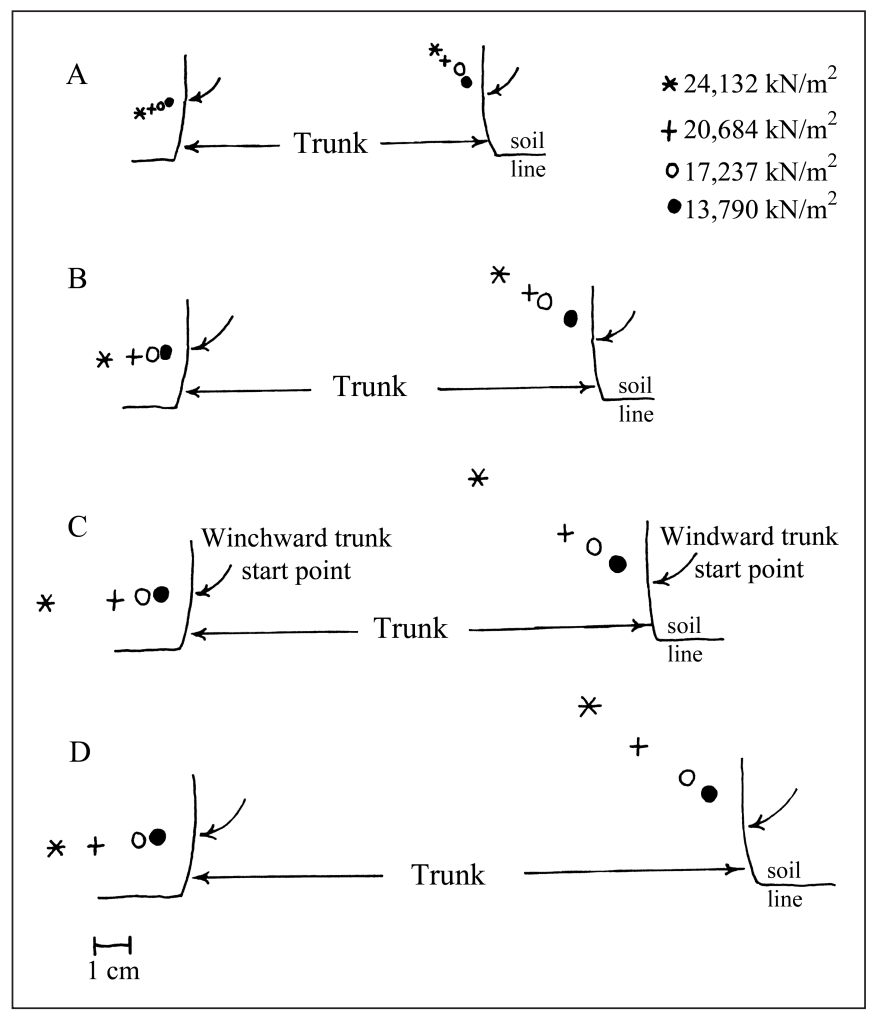

Figure 8. Trunk displacement winchward and windward for trees planted from $11 \mathrm{~L}(\mathrm{~A}), 103 \mathrm{~L}(\mathrm{~B}), 230 \mathrm{~L}(\mathrm{C})$, and $983 \mathrm{~L}$ (D) container sizes at four bending stresses $(n=8$, averaged across irrigation treatments). Bent arrow indicates position of trunk prior to winching. Horizontal trunk displacement on windward side $(\mathrm{mm})=[1.22$ $\times$ (trunk CSA $\div$ total root CSA in largest 10 roots) $]+[0.002 \times$ bending stress $\left.\left(\mathrm{kN} / \mathrm{m}^{2}\right)\right]-31.13 ; P<0.0001, R^{2}=0.56$. Vertical trunk displacement on windward side $(\mathrm{mm})=[0.17 \times($ trunk CSA $\div$ CSA largest single root) $]+[0.006 \times$ container volume $(L)]+[0.002 \times$ bending stress $\left.\left(\mathrm{kN} / \mathrm{m}^{2}\right)\right]-21.24 ; P<0.0001, \mathrm{R}^{2}=0.56$. years later. This suggests that deflected roots may remain in that position for many years without growing substantial roots in line with the root segment proximal to the deflection.

In conclusion, despite the increasing water stress with container volume, growth rates were identical for the three smallest container volumes in the first six years after planting. Greater resistance to horizontal trunk displacement and overturning was associated with abundant roots radiating straight from the trunk that rested on mineral soil. Planting from smaller containers increased the root CSA outside the root ball per unit trunk CSA and they grew in mineral landscape soil, which helped trees become anchored better than those planted from larger containers whose large roots mostly remained in the original container volume. Unlike the larger trees, those planted from the smallest containers retained the capacity to generate a root system similar to that found in nature (Lyford and Wilson 1964). This capacity appeared to diminish as red maple trees were retained in the nursery by shifting them to increasingly larger container volumes. The result was diminished anchorage due primarily to reduced root CSA growing from the container root ball and into landscape soil, lower root-soil plate mass, and the deflected nature of the main structural roots.

Acknowledgments. Thanks to the GreatSouthernTreeConference.org and the TREE Fund for partial funding.

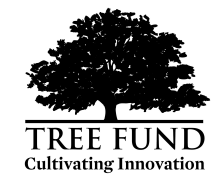

\section{LITERATURE CITED}

American Association of Nurserymen (AAN). 2004. American Standard for Nursery Stock, Z60.1. American National Standards Institute, Washington D.C., U.S.

Arnold, M.A. 2005. Planting depth and mulch thickness affect establishment of green ash (Fraxinus pennsylvanica) and Bougainvillea goldenraintree (Koelreuteria bipinnata). Journal of Arboriculture 31:163-170.

Arnold, M.A., and G.V. McDonald. 2009. Groundcovers, organic and inorganic mulches, and masonry surfaces differentially affect establishment and root zone characteristics of urban trees. Arboriculture \& Urban Forestry 35:232-240

Coutts, M.P. 1983. Root architecture and tree stability. Plant and Soil 71:171-188.

Coutts, M.P., and J.J. Philipson. 1977. The influence of mineral nutrition on the root development of trees. III. Plasticity of root growth in response to changes in the nutrient environment. Journal of Experimental Botany 28:1071-1075.

Duryea, M.L., E. Kampf, and R.C. Littell. 2007. Hurricanes and the urban forest: I. Effects on southeastern United States coastal plain species. Arboriculture \& Urban Forestry 33:83-97. 
Ennos, A.R. 1995. Development of buttress in rainforest trees: The influence of mechanical stress. In: M.P. Coutts and J. Grace (Eds.). Wind and Trees. pp. 293-301. Cambridge Univ. Press Cambridge.

Fourcaud, T., X. Zhang, and A. Stokes. 2008. Understanding the impact of root morphology on overturning mechanisms: A model approach. Annals of Botany 101:1267-1280.

Fraser, A.I., and J.B.H. Gardiner. 1967. Rooting and stability in Sitka spruce. Forestry Commission Bulletin 40, HMS, London.

Gilman, E.F., and C. Wiese. 2012. Root pruning at planting and planting depth in the nursery impact root system morphology and anchorage. Arboriculture \& Urban Forestry 38:232-239.

Gilman, E.F., and F.J. Masters. 2010. Effect of tree size, root pruning and production method on root growth and lateral stability of Quercus virginiana. Arboriculture \& Urban Forestry 36:281-291.

Gilman, E.F., and J.C. Grabosky. 2004. Mulch and planting depth affect live oak (Quercus virginiana Mill.) establishment. Journal of Arboriculture 30:311-317.

Gilman, E.F., and J.C. Grabosky. 2011. Quercus virginiana root attributes and lateral stability after planting at different depths. Urban Forestry \& Urban Greening 11:3-9.

Gilman, E.F., C. Harchick, and M. Paz. 2010a. Effect of tree size, root pruning and production method on establishment of Quercus virginiana. Arboriculture \& Urban Forestry 36:183-190.

Gilman, E.F., J.C. Grabosky, A. Stodola, and M.D. Marshall. 2003. Irrigation and container type impact red maple five years after landscape planting. Journal of Arboriculture 29:231-236.

Gilman, E.F., M. Paz, and C. Harchick. 2010b. Root ball shaving improves root systems on seven species in containers. Journal of Environmental Horticulture 28:13-18.

Gilman, E.F., R.J. Black, and B. Dehgan. 1998. Irrigation volume and frequency and tree size affect establishment rate. Journal of Arboriculture 24:1-9.

Harris, J.R., and E.F. Gilman. 1993. Production method affects growth and post-transplant establishment of 'East Palatka' holly. Journal of American Society for Horticulture Science 118:194-200.

Hewitt, A., and G.W. Watson. 2009. Bare root liner production can alter tree root architecture. Journal of Environmental Horticulture 27:99-104.

Iles, J.K., and A.M. Vold. 2003. Landscape tree cultivar preferences in Iowa, U.S. Journal of Arboriculture 29:331-336.

Iles, J.K., and M.S. Dossman. 1999. Effect of organic and mineral mulches on soil properties and growth of Fairview Flame red maple trees. Journal of Arboriculture 25:163-167.

Kamimura, K., K. Kitagawa, S. Saito, and H. Mizunaga. 2012. Root anchorage of hinoki (Chamaecyparis obtuse (Sieb. Et Zucc. Endl.) under the combined loading of wind and rapidly supplied water on soil: Analyses based on tree-pulling experiments. European Journal of Forest Research 131:219-227.

Lindström, A., and G. Rune. 1999. Root deformation in plantations of container-grown Scots pine trees: Effects on root growth, tree stability and stem straightness. Plant and Soil 217:29-37.

Lyford, W.H., and B.F. Wilson. 1964. Development of the root system of Acer rubrum L. Harvard Forestry Paper No. 10.

Marshall, M.D., and E.F. Gilman. 1998. Effects of container type on root growth and landscape establishment of Acer rubrum. Journal of Environmental Horticulture 16:55-59.

Mickovski, S.B., and R. Ennos. 2002. A morphological and mechanical study of the root systems of suppressed crown Scots pine Pinus sylvestris. Trees 16:274-280.

Ortega, U., J. Majada, A. Mena-Petite, J. Sanchez-Zabala, N. RodriguezItturrizar, K. Txarterina, J. Azpitarte, and M. Duñabeitia. 2006. Field performance of Pinus radiata D. Don produced in nursery with different types of containers. New Forests 31:97-112.

Paine, T.D., C.C. Hanlon, D.R. Pittenger, D.M. Ferrin, and M.K. Malinoski. 1992. Consequences of water and nitrogen management on growth and aesthetic quality of drought-tolerant woody landscape plants. Journal of Environmental Horticulture 10:94-99.

Roppolo, D.J., and R.W. Miller. 2001. Factors predisposing urban trees to sunscald. Journal of Arboriculture 27:246-254.

Salonius, P., K. Beaton, and B. Roze. 2000. Effects of cell size and spacing on root density and field performance of container-reared black spruce. Information Report M-X-208E, Canadian Forest Service, Atlantic Forestry Centre, Frederickton, New Brunswick, Canada.

Scharenbroch, B. 2009. A meta-analysis of studies published in Arboriculture \& Urban Forestry relating to organic materials and impacts on soil, tree, and environmental properties. Arboriculture \& Urban Forestry 35:221-231.

Singer, C.K., and C.A. Martin. 2009. Effect of landscape mulches and drip irrigation on transplant establishment and growth of three North American desert native plants. Journal of Environmental Horticulture 27:166-170.

Spomer, A. 1980. Container soil water relations: Production, maintenance, and transplanting. Journal of Arboriculture 6:315-320.

Stabler, L.B., and C.A. Martin. 2000. Irrigation regimens differently affect growth and water use efficiency of two southwest landscape plants. Journal of Environmental Horticulture 18:66-70.

Stokes, A. 1999. Strain distribution during anchorage failure of Pinus pinaster Ait. at different ages and tree growth response to windinduced root movement. Plant and Soil 217:17-27.

Struve, D.K., L. Burchfield, and C. Maupin. 2000. Survival and growth of transplanted large- and small-caliper red oaks. Journal of Arboriculture 26:162-169.

Tanaka, N., M.B. Samarakoon, and J. Yagisawa. 2012. Effects of root architecture, physical tree characteristics, and soil shear strength on maximum resistive bending moment for overturning Salix babylonica and Juglans ailantifolia. Landscape Ecological Engineering 8:69-79.

Watson, G.W. 1985. Tree size affects root regeneration and top growth after transplanting. Journal of Arboriculture 11:37-40.

\author{
Edward F. Gilman (corresponding author) \\ Environmental Horticulture Department \\ University of Florida \\ Gainesville, Florida, U.S. \\ egilman@ufl.edu
}

\section{Jason Miesbauer}

Environmental Horticulture Department

University of Florida

Current address:

The Morton Arboretum

Lisle, Illinois, U.S.

\section{Chris Harchick}

Environmental Horticulture Department

University of Florida

Gainesville, Florida, U.S.

Richard C. Beeson

Mid-Florida Research and Education Center

University of Florida

Apopka, Florida, U.S. 
Résumé. Certains déracinement d'arbres lors de tempêtes semblent être apparemment dus à une déflection de la croissance des racines qui s'est produite lors de phase de production en pépinière. La déflection des racines des sujets produits en pot peut produire un mauvais ancrage en raison d'une croissance racinaire insuffisante dans le sol ambiant (après la plantation), et la dimension du contenant au moment de la plantation peut avoir une influence sur la déflection des racines. Cette étude a été conçue pour évaluer le degré d'établissement, la croissance racinaire et l'ancrage six ans après la plantation d'Acer rubrum L. de quatre dimensions différentes provenant de quatre volumes correspondant de pots et avec deux régimes différents d'irrigation. L'impact de la présence d'un paillis sur le degré d'établissement et la croissance racinaire a aussi été évalué. Les arbres provenant des contenants les plus gros poussaient lentement les trois premières années en raison principalement d'un stress hydrique. L'inclinaison du tronc lors de tests de traction était supérieure en raison de la déflection des racines, d'une masse racinaire plus faible au sein de la motte originale et d'une diminution de la croissance racinaire dans le sol ambiant après la plantation, et ce avec l'accroissement en volume des contenants et des arbres. De manière contrastante avec le faible ancrage, les arbres les plus gros avaient la plupart de leurs grosses racines qui étaient retenues dans la motte originale de plantation, tandis que les plus grosses racines chez les arbres plus petits s'étaient développées plus librement hors de la motte suite à leur plantation. Ceci a produit des arbres plus stables avec plusieurs racines rigides et droites qui se développaient directement en profondeur dans le sol minéral ambiant hors de la motte originale lors des tests de traction. Les arbres plantés qui provenaient de contenants plus petits s'ancraient plus rapidement que les arbres plus gros et ils seront de ce fait plus stables faces aux tempêtes.

Zusammenfassung. Einige Bäume wurden während eines Sturmes hauptsächlich durch ihren verdrehten Wurzelballen innerhalb der Baumschulproduktion entwurzelt. Die Wurzelbiegung während der Container-Produktion kann zu schlechter Verankerung führen, weil nur unzureichendes Wachstum in die Peripherie des umgebenden Bodens stattfindet. Das Containervolumen und die Baumgröße während der Pflanzung können die Wurzelbiegung beeinflussen. Diese Studie wurde angelegt, um das Anwachsen, Wurzelwachstum und Verankerung bei vier Größen von Acer rubrum L. Bäumen in vier entsprechenden Containergrößen nach sechs Jahren zu bewerten, während sie mit zwei unterschiedlichen Systemen bewässert wurden. Der Einfluss von Mulch auf Anwachsen und Wurzelwachstum wurde ebenfalls bewertet. Die
Bäume aus den größten Containern wuchsen während der ersten drei Jahre aufgrund von Wasserstress am langsamsten. Die Stammbiegung während des Zugversuchs nahm aufgrund von größerer Wurzelbiegung, weniger Masse auf der Wurzelsohle und reduziertem Wurzelwachstum nach außen mit zunehmender Baumgröße und Container-Volumen zu. Im Vergleich zu den schlecht verankerten größeren Bäumen, die ihre meisten Wurzeln innerhalb des ursprünglich gepflanzten Wurzelballens hatten, wuchsen die Wurzeln von kleineren Bäumen frei in den umgebenden Boden hinein. Das führte zu stabilen Bäumen mit vielen steifen, geraden Wurzeln, die sich während des Ziehens durch den mineralischen Landschaftsboden drückten. Gepflanzte Bäume aus kleineren Containern schienen sich schneller zu verankern als Bäume aus größeren Containern und würden daher im Sturm auch stabiler sein.

Resumen. Algunos árboles se desenraizan en las tormentas debido aparentemente a las deflexiones de las raíces que se producen durante la producción en viveros. La deflexión de la raíz en un contenedor de vivero puede llevar a un mal anclaje debido al crecimiento insuficiente de la raíz en el suelo del paisaje, y la relación volumen del contenedor / tamaño del árbol en la plantación puede influir en la malformación de la raíz. Este estudio fue diseñado para evaluar el establecimiento, crecimiento de la raíz, y el anclaje seis años después de la plantación de árboles de Acer rubrum L. de cuatro tamaños diferentes para cuatro volúmenes de contenedores correspondientes y su mantenimiento con dos regímenes de riego. También se evaluó el impacto del mulch en el establecimiento y crecimiento de las raíces. Los árboles de los recipientes más grandes crecieron más lento en los tres primeros años debido principalmente a la falta de agua. La inclinación del tronco durante las pruebas de resistencia aumentó debido a una mayor deflexión de la raíz, menor masa de en la relación suelo-raíz, y reducido crecimiento de las raíces en el suelo del paisaje con el aumento de volumen del contenedor y el tamaño del árbol. En contraste con los mal anclados, los árboles más grandes tenían la mayor parte de sus grandes raíces retenidas en el volumen original de la bola de la raíz, con raíces más grandes en los árboles de recipientes más pequeños creciendo libremente en el suelo del paisaje. Esto dio lugar a árboles estables con muchas raíces rígidas rectas que durante la prueba empujan hacia abajo contra el suelo mineral, fuera de la bola de la raíz. Los árboles plantados en contenedores más pequeños parecen anclarse antes que los árboles de contenedores más grandes y serán más estables en una tormenta. 